\title{
РЕАЛИЗАЦИЯ НАЦИОНАЛЬНЫХ ИНТЕРЕСОВ РОССИИ В СОТРУДНИЧЕСТВЕ СО СТРАНАМИ АТР "
}

\author{
(C) 2020 Алексеев Пётр Викторович \\ кандидат экономических наук, \\ ведущий научный сотрудник Института мировой экономики и международных финансов \\ Финансовый университет при Правительстве Российской Федерации, Россия, Москва \\ E-mail:palekseev@fa.ru
}

В настоящее время вопросы реализации национальных интересов России в Азиатско-Тихоокеанском регионе (АТР) являются приоритетными направлениями в развитии российской экономики. Национальные стратегические интересы России в АТР являются составной частью общенациональной внешнеэкономической стратегии государства. Исходя из анализа современной ситуации в данной сфере, в статье предложены направления реализации данных интересов в контексте общенациональной внешнеэкономической стратегии развития Российской Федерации.

Ключевые слова: внешнеэкономическая политика; Азиатско-Тихоокеанский регион; российскокитайское инвестиционное сотрудничество; инвестиции; территории опережающего развития; инфраструктура

Проблемам социально-экономического развития Дальнего Востока России, привлечения в него инвестиций, трудовых ресурсов, интеграции его в мировое хозяйство в последние годы уделяется большое внимание со стороны государства и экспертов.

В 2013 г. Правительственной комиссией по вопросам социально-экономического развития Дальнего Востока была утверждена новая модель социально-экономического развития ДВФО, основанная на экспорте в страны АТР готовых товаров (работ, услуг), производимых на территории ДВФО, создании конкурентоспособного инвестиционного климата, привлечении прямых инвестиций, в том числе иностранных, росте деловой активности, развитии малого и среднего предпринимательства, создании конкурентоспособных территорий опережающего развития. Новая модель предусматривает также реорганизацию системы управления социальноэкономическим развитием ДВФО для ее приведения в соответствие с задачами опережающего развития восточных территорий Российской Федерации.

С учетом вышеприведенной новой модели в 2019 г. была разработана государственная программа «Социально-экономическое развитие Дальневосточного федерального округа» [1], в которой сформированы следующие приоритеты:
- создание в ДВФО конкурентоспособных (в сравнении с соседними странами АТР) условий ведения хозяйственной деятельности, необходимых для опережающего развития экономики и социальной сферы;

- обеспечение крупномасштабного притока инвестиций в проекты, осуществляемые на территории ДВФО;

- развитие инфраструктуры для обеспечения реализации инвестиционных проектов и создания новых рабочих мест;

- увеличение объема экспортных сделок организаций ДВФО со странами АТР;

- обеспечение положительного значения прироста населения, а также его закрепление в восточных регионах страны на основе повышения уровня и качества жизни, развитие человеческого капитала.

Исходя из указанных приоритетов государственной политики сформулированы следующие цели Программы:

- повышение уровня социально-экономического развития ДВФО;

- обеспечение потребности в трудовых ресурсах и закрепление населения в ДВФО;

- повышение качества жизни граждан ДВФО.

Для достижения целей Программы будут решены следующие задачи:

Статья подготовлена по результатам исследований, выполненных за счет бюджетных средств по государственному заданию Финуниверситета. 
- формирование и развитие в ДВФО территорий опережающего социально-экономического развития (далее - ТОСЭР) с благоприятными условиями для привлечения инвестиций;

- содействие реализации инвестиционных проектов в ДВФО;

- привлечение инвестиционных и трудовых ресурсов в ДВФО;

- организационно-правовое обеспечение ускоренного развития ДВФО и развитие центров экономического роста субъектов Российской Федерации, входящих в ДВФО;

- создание условий для устойчивого социально-экономического развития Курильских островов [1].

Для решения поставленных задач необходимы крупномасштабные инвестиции в экономику ДВФО. Целенаправленная работа Правительства РФ по улучшению инвестиционного климата в ДВФО и созданию территорий опережающего социально-экономического развития привела к увеличению притока прямых российских и иностранных инвестиций в макрорегион. По данным Заместителя Председателя Правительства РФ Ю.П. Трутнева, по состоянию на 27 мая 2019 г. на территории Дальнего Востока реализуется 1597 инвестиционных проектов, для которых предоставляются меры государственной поддержки (налоговые льготы резидентам ТОСЭРов, инфраструктурная поддержка, льготное кредитование Фонда развития Дальнего Востока). Общий объем инвестиций по данным проектам составляет 3,8 трлн. рублей. Будет сформировано 136,9 тыс. рабочих мест. Фактически введены в эксплуатацию 214 предприятий [2].

Что касается притока в ДВФО прямых иностранных инвестиций (далее - ПИИ), то в настоящее время наиболее перспективными партнерами дальневосточных регионов России в этой сфере являются страны, входящие в форумы АТР - АТЭС (Азиатско-Тихоокеанское сотрудничество) и АСЕАН (Ассоциация государств Юго-Восточной Азии). В настоящее время торгово-экономическое сотрудничество России со странами АТР развивается достаточно динамично и благодаря этому Россия стабильно увеличивает объем торговли. Инвестиционное сотрудничество развивается не столь быстрыми темпами, при этом основными партнерами России в инвестиционном сотрудничестве в АТР являются Китай, Сингапур, США, Япония, Республика Корея, Вьетнам, Австралия. Инвестиции других стран АТР в Россию и российские инвестиции в них сравнительно незначительны.

В настоящее время наиболее надежным стратегическим партнером России в сфере инвестиционного сотрудничества является Китай, осуществляющий масштабные инвестиции российскую экономику (таблица 1).

Согласно данным Банка России, на 1 июля 2019 г. объем накопленных китайских ПИИ в Россию составил 3502 млн. долл., а объем накопленных российских ПИИ в КНР составил 284 млн. долл. [3]

В настоящее время на уровне глав России и Китая официально утверждена цель доведения объема китайских ПИИ в Россию до 12 млрд. долл. к 2020 году. С целью развития инвестиционного сотрудничества в 2014 г. создана Российско-Китайская Межправительственная комиссия по инвестиционному сотрудничеству. На начало 2020 г., в портфеле Комиссии находятся 70 инвестиционных проектов с общим объемом инвестиций 112 млрд. долл. [2].

В ходе шестого заседания Межправительственной комиссии 26 ноября 2019 г. были дополнительно одобрены российско-китайские инвестиционные проекты в различных секторах экономики, в том числе:

- строительство горно-обогатительного комбината на базе месторождения редких металлов в Иркутской области между двумя метал-

Таблица 1. Прямые иностранные инвестиции из Китая в Россию и из России в Китай в 2008 - 1-м полугодии 2019 гг., млн. долл. США

\begin{tabular}{|l|c|c|c|c|c|c|c|c|c|c|c|c|}
\hline $\begin{array}{l}\text { Направление } \\
\text { инвестиций }\end{array}$ & 2008 & 2009 & 2010 & 2011 & 2012 & 2013 & 2014 & 2015 & 2016 & 2017 & $\begin{array}{c}2018 \\
(1-\mathrm{e} \mathrm{полу-} \\
\text { годие })\end{array}$ \\
\hline $\begin{array}{l}\text { Инвестиции } \\
\text { КНР в Россию }\end{array}$ & 240 & 410 & 594 & 568 & 660 & 4080 & 6872 & 5401 & 345 & 140 & -13 & 139 \\
\hline $\begin{array}{l}\text { Инвестиции } \\
\text { России в КнР }\end{array}$ & 60 & 52 & 35 & 31 & 29,9 & 14 & 54 & 11 & 6 & 33 & 35 & 21 \\
\hline
\end{tabular}

Примечание: в таблице отражено сальдо операций платежных балансов. Источник: http://www.cbr.ru/statistics. Дата обращения: 21.01.2020. 
лургическими холдингами - Челябинским трубопрокатным заводом и китайской компанией «Inner Mongolia Baotou Steel»;

- создание крупнейшего в России игрока в сфере электронной торговли в рамках партнерства Российского фонда прямых инвестиций, Alibaba Group, Mail.ru Group, «Мегафона»;

- создание Российско-Китайского научнотехнологического инновационного фонда;

- создание Российско-Китайского фонда региона Большого Залива и ряд других [2].

Значительным потенциалом в привлечении китайских и других иностранных ПИИ в ДВФО обладают ТОСЭР, создание и функционирование которых регулируется Федеральным законом от 29.12.2014 № 473-Ф3 «О территориях опережающего социально-экономического развития в Российской Федерации». Согласно ст. 2 Федерального закона от 29.12.2014 г. № 473-ФЗ, ТОСЭР представляет собой часть территории субъекта Российской Федерации, на которой в соответствии с решением Правительства РФ установлен особый правовой режим осуществления предпринимательской и иной деятельности в целях формирования благоприятных условий для привлечения инвестиций, обеспечения ускоренного социально-экономического развития и создания комфортных условий жизнедеятельности населения. Первыми в истории России стали ТОСЭРы «Хабаровск», «Комсомольск» и «Надеждинский», созданные в ДВФО в 2015 г.”

По данным Ю.П. Трутнева, по состоянию на 22 августа 2018 г., в практическую стадию реализации в ТОСЭРах и свободном порту Владивосток с участием китайского капитала перешло 32 проекта стоимостью 4,2 млрд. долл. Это 7\% общего объема инвестиций, привлеченных на Дальний Восток [4].

Несмотря на большое количество созданных ТОСЭРов, в настоящее время их потенциал в привлечении ПИИ используется, на наш взгляд, недостаточно, прежде всего в связи с высокими экономическими рисками инвестирования, а также недостаточно развитой транспортной, энергетической, инвестиционной, социальноэкономической инфраструктурой ДВФО. Во многом сложившаяся ситуация обусловлена недостаточной проработанностью ряда важных вопросов, связанных с созданием и функционированием ТОСЭРов, в том числе:

- место ТОСЭРов в национальной стратегии социально-экономического развития России, включая развитие инфраструктуры;

- вопросы удовлетворения потребности ТОСЭРов в рабочей силе и интеграции с университетами и профессиональными учебными заведениями для подготовки квалифицированных кадров;

- вопросы обеспечения доступа предприятий в ТОСЭРах к финансово-кредитным институтам;

- внедрение высоких экологических стандартов;

- ограничение рисков, связанных с деятельностью ТОСЭРов, в том числе экономических и экологических [5].

Очевидно, что для обеспечения успешного развития ТОСЭРов, расположенных в Дальневосточном регионе России, целесообразно использовать многолетний опыт деятельности экономических зон с особым режимом хозяйственной деятельности в России и Китае ${ }^{* * *}$. Опыт

\footnotetext{
По состоянию на 1 января 2020 г. в восьми регионах Дальнего Востока созданы 21 ТОСЭР, в них реализуют свои проекты свыше 386 резидентов, благодаря чему будет создано более 64939 рабочих мест. (URL: https://minvr. ru/press-center/news/7957. Дата обращения: 21.01.2020). Наряду с ТОСЭР, созданными на Дальнем Востоке, по состоянию на 1 января 2020 г. созданы 90 тОСЭРов в Кемеровской, Ростовской, Иркутской, Челябинской, Пензенской, Смоленской, Мурманской областях, республиках Татарстан, Башкортостан, Коми, Карелия, Дагестан и других субъектах Российской Федерации. (URL: http://www.garant.ru. Дата обращения: 21.01.2020).

** Первые ОЭЗ в Китае были созданы в 1980 г. (в городах Шеньчжень, Чжухай, Шаньтоу, Сямынь, Хайнань) в рамках политики реформ и либерализации внешнеэкономической деятельности страны. Главная задача первых ОЭЗ - привлечение и использование иностранных инвестиций и технологий посредством введения в них особого юридического статуса и льготного налогового режима. Основные формы предприятий в них экспортно-ориентированные совместные или иностранные предприятия. Уже в 1981 г. эти ОЭЗ привлекли около 60\% ПИИ в Китай. В настоящее время в Китае функционируют 5 ОЭЗ. Кроме того, в стране действуют 131 зона экономического и технологического развития, 105 зон высоких и новых промышленных технологий, 15 свободных таможенных зон, 14 трансграничных свободных экономических зон, 15 экспортно-промышленных и 29 других типов экономических зон. (Источник: Семенов Ф.В. Использование опыта свободных экономических зон Китая в России/Россия и Китай: проблемы стратегического взаимодействия: сборник Восточного Центра. 2016. № 17. С. 43).
} 
Китая свидетельствует, что важными условиями успешного формирования и функционирования особых зон, наряду с активной государственной поддержкой строительства транспортной, энергетической и социально-экономической инфраструктуры, является широкое использование налоговых и финансовых стимулов".

Для обеспечения развития транспортной инфраструктуры в ДВФО целесообразно законодательно установить для инвесторов, участвующих в её создании, возможность получения субсидий в размере 5\% капитальных затрат инвесторов по контрактам. Субсидии могут выдаваться из федерального фонда для инфраструктурных инвестиций, о создании которого объявлено Первым Заместителем Председателя Правительства - Министром финансов РФ А. Г. Силуановым 24 мая 2019 г.

Одним из факторов, сдерживающих развитие ТОСЭРов, является недостаточное использование налоговых стимулов для инвестиций. По справедливому мнению профессора А.Г. Зельднера, налоговая система ТОСЭРов во многом скопирована с Федерального закона от 22 июля 2005 г. № 116 «Об особых экономических зонах в Российской Федерации» [6]. В этой связи следует отметить, что за более чем 10 лет функционирования ОЭЗ проявились определенные ее недостатки.

Как показывает анализ налоговой деятельности ОЭЗ, объем уплаченных резидентами налоговых и таможенных платежей на 1 января 2017 г. составил 38,8 млрд. руб., а сумма налоговых и таможенных льгот всего 28,0 млрд. руб., что составляет 72,2\% от уплаченных налогов [7]. Согласно данным Счетной палаты РФ, по сути, за каждый рубль налоговых льгот зоны отдают в бюджет 1,38 рубля. Такое соотношение, по справедливому мнению профессора А.Г. Зельднера, тормозит осуществление технологических и инновационных разработок. Для решения этой проблемы, по мнению А.Г. Зельднера, целесообразно внести поправки в действующее законо- дательство, введя льготы по налогу на всю прибыль при условии ее использования на развитие бизнеса резидентами ТОСЭР [6].

В настоящее время, по мнению экспертов, вопросы реализации национальных интересов России в АТР являются приоритетными направлениями в развитии российской экономики. Национальные стратегические интересы России в АТР являются составной частью общенациональной внешнеэкономической стратегии государства [8]. В контексте общенациональной внешнеэкономической стратегии развития Российской Федерации интеграция России со странами АТР должна включать следующие приоритетные направления:

1. Для обеспечения конкурентоспособности Дальневосточного региона России в АТР разработать национальную программу развития Дальнего Востока России на период до 2025 года и с перспективой до 2035 года. В рамках национальной программы целесообразно объединить, интегрировать мероприятия российских национальных проектов и госпрограмм, долгосрочные отраслевые планы ведомств и инфраструктурных компаний, стратегии развития всех дальневосточных регионов. Национальная программа развития Дальнего Востока должна содержать предметные, конкретные измерения и измеримые показатели.

2. Наряду с поступательным развитием традиционных отраслей, обеспечивающих внешнеторговый оборот Дальневосточного региона со странами АТР, предусмотреть в национальной программе развития Дальнего Востока ускоренное развитие сферы образования, науки и международного сотрудничества в сферах, которые определяют тенденции глобального прогресса, научнообразовательные центры мирового уровня, центры «цифрового развития», обеспечивающие технологии хранения и передачи больших данных, а также кибербезопасность. Обеспечить темпы экономического роста российского Дальнего Востока на уровне $6 \%$.

\footnotetext{
Важность соблюдения вышеперечисленных условий подтверждается негативным опытом функционирования в России свободных экономических зон (СЭ3) в 1991-2005 гг. Анализ данного опыта свидетельствует, что в силу искусственного характера их формирования, которое не подкреплялось соблюдением необходимых условий их успешного формирования и функционирования, они превратились в каналы для утечки капитала. На практике в деятельности СЭЗ наблюдалось несоответствие инвестиционной, производственной и внешнеэкономической деятельности хозяйствующих субъектов российскому законодательству, получил распространение теневой бизнес, отмечалась тенденция осложнения криминогенной обстановки. Все это обусловило неэффективность проекта формирования СЭЗ в тот период (Источник: Павлов П.В. Проблемы развития особых экономических зон в России: правовые и организационные аспекты//Вестник Российской таможенной академии. 2015. № 1. С. 41).
} 
3. Продолжить развитие ТОСЭРов со льготными налоговыми условиями, упрощенными административными процедурами и другими привилегиями в России, которые создаются для привлечения инвестиций, ускоренного развития экономики и улучшения жизни населения. C этой целью внести поправки в действующее законодательство, введя льготы по налогу на всю прибыль при условии ее использования на развитие бизнеса резидентами ТОСЭР.

4. Законодательно установить для инвесторов, участвующих в создании транспортной инфраструктуры в ДВФО, возможность получения субсидий в размере 5\% капитальных затрат инвесторов по инвестиционным контрактам, выдаваемых из федерального фонда для инфраструктурных инвестиций.

5. Для наиболее эффективного использования транзитного положения Дальневосточно- го макрорегиона и реализации логистического потенциала Дальнего Востока провести модернизацию Байкало-Амурской и Транссибирской магистралей, продолжить развитие дальневосточных портов и Северного морского пути, что кардинально усилит транспортную связанность АТР и Европы.

6. На современном уровне обустроить пограничные переходы на Дальнем Востоке, сделать более удобной для граждан, бизнеса работу таможенных, контрольных, пограничных и других служб, работающих на границе [8].

Вышеприведенные меры направлены на реализацию высокого экономического потенциала и национальных интересов нашей страны в Азиатско-Тихоокеанском регионе в интересах обеспечения устойчивого развития Дальневосточного региона.

\section{Библиографический список}

1. Государственная программа «Социально-экономическое развитие Дальневосточного федерального округа» (утверждена Постановлением Правительства РФ от 29 марта 2019 г. № 361). URL: www.garant.ru (дата обращения: 21.01.2020).

2. URL: http://government.ru/news/36821. Дата обращения: 20.01.2020.

3. URL: http://www.cbr.ru/statistics. Дата обращения: 21.01.2020.

4. URL: http://government.ru/news/33726. Дата обращения: 21.01.2020.

5. Алексеев П.В. Об условиях успешного создания и функционирования территорий опережающего социальноэкономического развития на Дальнем Востоке России // Экономические науки. 2018. № 4. С. 99-102.

6. Зельднер А.Г. Государственные преференции привлечения инвестиций в развитие территорий опережающего социально-экономического развития // Вопросы экономики и права. 2018. №6. С. 82.

7. URL: http://audit.gov.ru/press-center/news/29969. Дата обращения: 21.01.2020.

8. Реализация национальных интересов Российской Федерации в сотрудничестве со странами АТР: монография / Под ред. В.В. Перской, Е.С. Соколовой.- Москва: ИНФРА-М, 2020. С. 150. 